\title{
The impact of thyroid function on the occurrence of metabolic syndrome in obese children and adolescents
}

\author{
Wpływ czynności tarczycy na wystąpienie zespołu metabolicznego w grupie otyłych dzieci \\ i młodzieży
}

\author{
1,2Anna Ruszała, 1,2Małgorzata Wójcik, 1,2Jerzy B. Starzyk
}

${ }^{1}$ Department of Paediatric and Adolescent Endocrinology, Chair of Paediatrics, Paediatric Institute, Jagiellonian University Medical College, Krakow, Poland

${ }^{2}$ Children's University Hospital in Krakow, Poland

\begin{abstract}
Introduction: Thyroid axis abnormalities are common in obese patients. Their contribution in the development of metabolic obesity complications remains unclear.

Aim of study: To assess the influence of thyroid axis dysfunction on the occurrence of metabolic obesity complications.

Material and methods: A cross-sectional review of the thyroid function in 100 obese patients (59 girls and 41 boys, mean age 13.5 years) with alimentary obesity (mean standardised body mass index [BMI SDS] in boys 4.175 and girls 4.723 ) complicated by metabolic syndrome (MS) diagnosed on the basis of the IDF 2006 criteria (MS, 25 patients) and uncomplicated (75 patients). TSH, fT4, fT3 thyroid peroxidase antibodies (TPOAb), and thyroglobulin antibodies (TGAb) were assessed in a single fasting blood sample. Results: There was no case of overt thyroid disease within the whole analysed group. There were no significant differences in mean $\mathrm{TSH}, \mathrm{fT} 4$, and fT3 levels in patients with and without MS $(2.7 \mu \mathrm{lU} / \mathrm{ml}$ vs. $3.0 \mu \mathrm{lU} / \mathrm{ml}, 14.5 \mathrm{vs}$. 14.0 pmol/l, and 5.6 vs. 6.2 , respectively; $p>0.05)$. In the MS group only two patients (8\%) presented with a TSH level above the upper limit of the normal range; in the group without MS elevated TSH was noticed in 18 (24\%) patients. The maximal value of TSH (10.44 $\mu \mathrm{lU} / \mathrm{ml})$ was noticed in one boy without MS. Positive TPOAb and/or TGAb were present in $11 \%$ of all patients: two patients (8\%) with MS and nine (12\%) without MS. Conclusions: Isolated increased TSH level is common in obese adolescents, although there is no correlation between TSH, fT3, and fT4 levels and BMI SDS value. Isolated increased TSH level is not associated with the occurrence of MS in obese adolescents. The occurrence of asymptomatic autoimmune thyroiditis (AITD) in obese adolescents is more common than in the general population.
\end{abstract}

Key words:

obesity, metabolic syndrome, thyroid.

\section{Streszczenie}

Wstęp: Zaburzenia funkcji osi tarczycowej są częste u pacjentów otyłych. Ich znaczenie w rozwoju metabolicznych powikłań otyłości pozostaje niejasny.

Cel badania: Ocena wpływu zaburzeń funkcji tarczycy u pacjentów otyłych na wystąpienie u nich powikłań metabolicznych.

Materiały i metody: Ocena funkcji tarczycy w grupie 100 pacjentów (59 dziewcząt, 41 chłopców; średni wiek 13,5 roku) z otyłością prostą (średni BMI SDS u chłopców 4,175 i u dziewcząt 4,723) z zespołem metabolicznym rozpoznanym na podstawie kryteriów IDF 2007 ZM (ZM, 25 pacjentów) i bez. U wszystkich wykonano oznaczenie stężeń TSH, fT4, fT3 przeciwciał przeciw tyreoperoksydazie tarczycowej (TPOAb) i przeciwciał przeciwko tyreoglobulinie (TGAb) w pojedynczej próbce krwi.

Wyniki: W analizowanej grupie nie stwierdzono przypadku jawnej niedoczynności tarczycy. Nie było istotnych statystycznie różnic ( $p$ > 0,05) średniej wartości TSH, fT4 i fT3 u pacjentów z ZM i bez ZM (odpowiednio: 2,7 $\mu \mathrm{lU} / \mathrm{ml}$ vs 3,0 $\mu \mathrm{lU} / \mathrm{ml}, 14,5$ vs 14,0 pmol/l i 5,6 vs 6,2 pmol/l). W grupie spełniającej kryteria ZM $(n=25)$ tylko dwie osoby $(2 / 25 ; 8 \%)$ miały stężenie TSH powyżej górnej granicy normy (N: 0,3-4,0 $\mu \mathrm{lU} / \mathrm{ml})$. W grupie bez ZM zwiększone stężenie TSH stwierdzono u 18 (18/75; 24\%) pacjentów. Maksymalną wartość TSH (10,44 $\mu \mathrm{IU} / \mathrm{ml})$ odnotowano u chłopca bez ZM. Dodatnie miano przeciwciał przeciwtarczycowych (TPOAb i/lub TGAb) było obecne u 11\% pacjentów: 2 pacjentów (2/25; 8\%) z ZM i u 9 (9/75; $12 \%)$ bez ZM.

Wnioski: Izolowane zwiększenie stężenia TSH jest częste u otyłych nastolatków, chociaż nie występuje zależność pomiędzy stężeniem TSH, fT3 ani fT4 a wartością BMI SDS. Izolowane zwiększenie stężenia TSH nie ma związku z występowaniem ZM u młodzieży.

\section{Słowa kluczowe:}

otyłość, zespół metaboliczny, tarczyca. 


\section{Introduction}

Obesity and its consequences have become a significant health problem nowadays. By 2030 an estimated 38\% of the world's adult population will be overweight, and another $20 \%$ will be obese [1]. This phenomenon is associated with increased morbidity because excessive fat tissue is a source of many regulatory factors. Fat tissue hormones and cytokines can directly and indirectly affect many of the body's functions. One of them is the thyroid axis. Obese people are often found to present increased thyrotropin (TSH) concentration levels and changes in the ratio between the thyroid hormones: triiodothyronine and thyroxine, although both levels are usually within the normal range [2-4]. The aetiology of these processes is still unclear. It is hypothesised that at least four mechanisms are involved in this phenomenon: 1) an adaptive process to increased leptin production by fat tissue, 2) insulin resistance and concomitant chronic low-grade inflammation leading to abnormal mitochondrial function and abnormal pattern of energy expenditure, 3) abnormal activity of deiodinases and relative thyroid hormone resistance, and 3) development of autoimmune thyroid disease (AITD) [2-6]. The first three mentioned effects seem to be reversible after weight reduction, leading to normalisation of free triiodothyronine (fT3) and free thyroxine (fT4) ratio. The effect of weight reduction on normalisation of TSH remains controversial $[7,8]$. Although the clinical implications of thyroid axis dysfunction in obesity are not well investigated, some studies suggest that they may contribute to the worsening of metabolic complications [2]. According to some studies, thyroid dysfunction can be an additional risk factor that should be taken into consideration when calculating individual cardiometabolic risk [9].

The aim of the study was to assess the influence of thyroid axis dysfunction on the occurrence of metabolic obesity complications. For this purpose, we compared the thyroid axis function in adolescents with uncomplicated nutritional obesity and obesity complicated by the occurrence of metabolic syndrome (MS).

\section{Material and methods}

The study included 100 patients (59 girls and 41 boys) between five and 18 years of age (mean age 13.5 years) with alimentary obesity (mean standardised body mass index [BMI SDS] in boys 4.175 and in girls 4.723) and without history of thyroid diseases. Patients were recruited from the Clinic of Paediatric and Adolescent Endocrinology University Children's Hospital in Krakow, Poland. In all patients, evaluation was performed before starting the process of weight reduction. BMI was calculated from the following equation: $\mathrm{BMI}=$ body weight $(\mathrm{kg})$ / body height $(\mathrm{m})^{2}$. Obesity was defined by BMl above the $95^{\text {th }}$ percentile for sex and age [10]. Hypertension was diagnosed when systolic and/or diastolic value was above the $95^{\text {th }}$ percentile according to sex and height [10]. MS was diagnosed on the basis of the IDF 2006 criteria [10]. Glucose, HDL-cholesterol, and triglyceride concentrations were measured in blood samples collected after eight hours of fasting. TSH, fT4, fT3, thyroid peroxidase antibodies (TPOAb), and thyroglobulin antibodies (TGAb) were determined in a single fasting blood sample. Normal ranges were defined as: TSH 0.3-4.0 $\mu \mathrm{lU} / \mathrm{ml}$, fT4 10-25 pmol/l, fT3 3.0-8.1 pmol/l, TPOAb < $30 \mathrm{lU} / \mathrm{ml}$, and TGAb $<30 \mathrm{IU} / \mathrm{ml}$. TSH, fT3, and fT4 were measured using immunochemistry method with an Advia Centaur machine, and TPOAb and TGAb using radioimmunoassay (RIA) method with a Brams machine.

\section{Statistical analysis}

To compare the two sets of data, Student's t-test or twosided Mann-Whitney $U$ test was used. For a correlation analysis, the correlation coefficient $(\mathrm{R})$ and regression analysis were used. Statistically significant results were assumed for which the probability value was less than 0.05 .

\section{Results}

There was no case of overt hypothyroidism within the whole analysed group. We did not notice abnormal values of fT3 or fT4. There were no significant differences in mean TSH, fT4, and fT3 levels in patients with and without MS $(2.7 \mu \mathrm{lU} / \mathrm{ml}$ vs. $3.0 \mu \mathrm{lU} / \mathrm{ml}, 14.5 \mathrm{vs} .14 .0 \mathrm{pmol} / \mathrm{l}$, and $5.6 \mathrm{vs} .6 .0 \mathrm{pmol} / \mathrm{l}$, respectively; $p>0.05$ ) (Fig. 1). There was no significant correlation between BMI SDS and TSH, fT4, or fT3 levels ( $R=0.008 ;-0.04$; -0.03 , respectively; $p>0.05$ ) (Fig. 2 ). In the group that met IDF criteria of MS $(n=25)$ only two $(2 / 25,8 \%)$ presented with TSH above the upper limit of the normal range. For comparison, in the group without MS elevated TSH was noticed in $18(18 / 75$, $24 \%)$ patients. Sub analysis performed for girls and boys revealed that among girls with MS two $(2 / 14,14 \%)$ presented with elevated TSH value vs. 11 (11/4524\%) in the group without MS. In boys with MS no one presented with elevated TSH value vs. seven $(7 / 30,23 \%)$ in the group without MS. The differences were not significant. The maximal value of TSH $(10.44 \mathrm{ulU} / \mathrm{ml})$ was noticed in one boy without MS. Positive antithyroid autoantibodies (TPOAb and/or TGAb) were present in $11 \%$ of all patients: 2 patients $(2 / 25,8 \%)$ with MS (both girls, both with normal TSH) and 9 (9/75, 12\%) without MS (2 with elevated TSH [boys only], seven with normal TSH [5 girls]). Elevated TSH was not associated with autoimmunity, and only two patients with higher TSH were positive for antithyroid antibodies.

\section{Discussion}

Thyroid axis function in obese patients has been investigated widely in recent years. It has been shown that TSH level above upper laboratory normal range is more prevalent in obese patients than in healthy pears. According to literature data, $10-24 \%$ of obese children and adolescents present with elevated TSH in the absence of thyroid disease $[3,13]$, similarly 
A

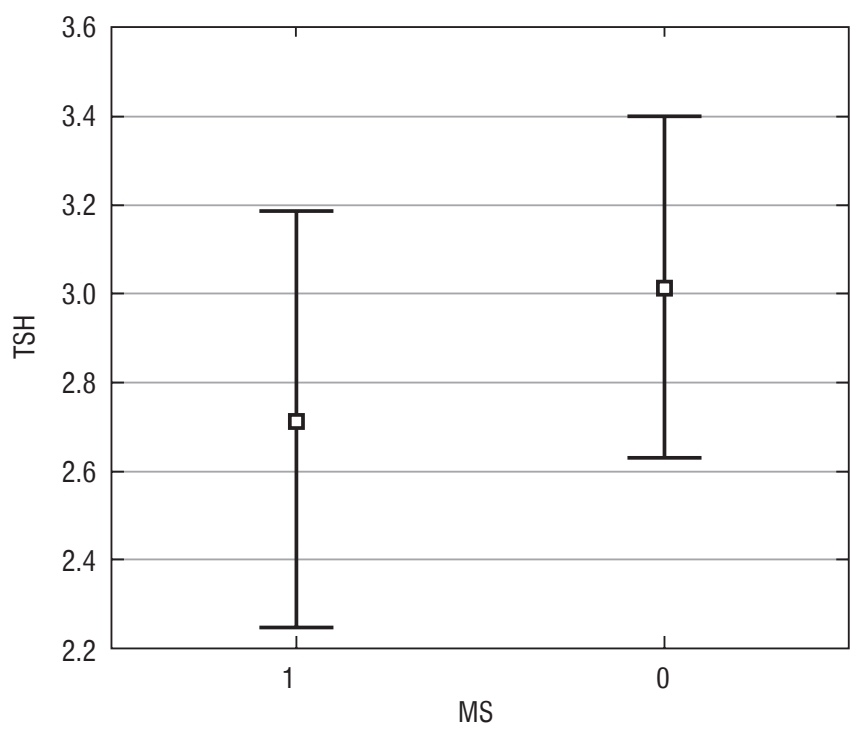

口 średnia I średnia $\pm 95 \mathrm{Cl}$

C

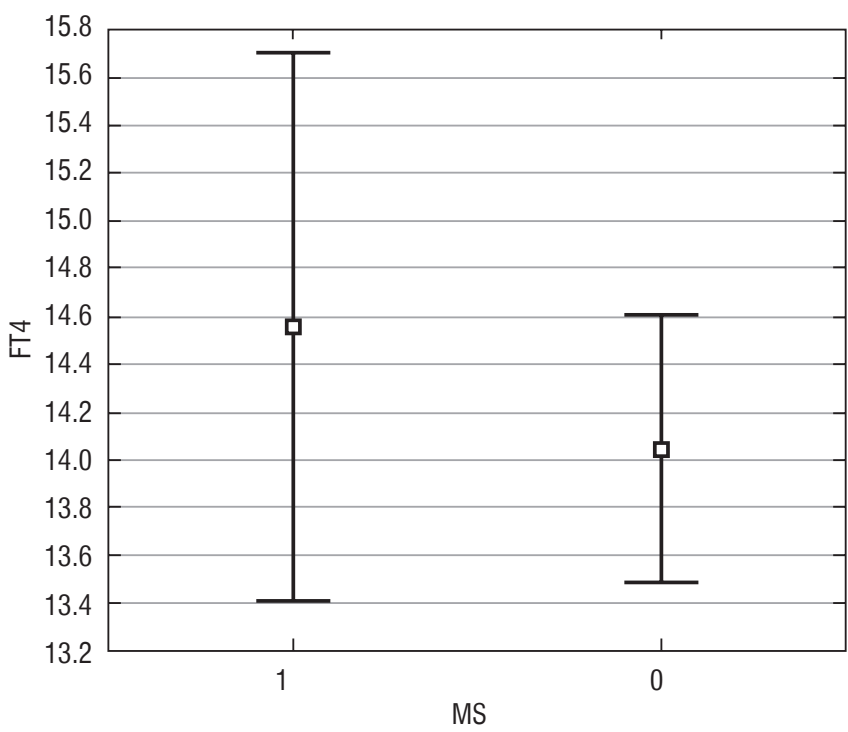

口 średnia I średnia $\pm 95 \mathrm{Cl}$

Figure 1. TSH (A), fT3 (B), and fT4 (C) values in patients without MS (0) and with MS (1)

as in the present study (20\%). Although the mechanism of such an increase in TSH level in obese patients remains unclear, it is usually not caused by primary thyroid dysfunction (as in subclinical/overt hypothyroidism). In adults the TSH value increases proportionally to the degree of obesity [14-16]. Such a correlation is uncertain in children because the literature data
B

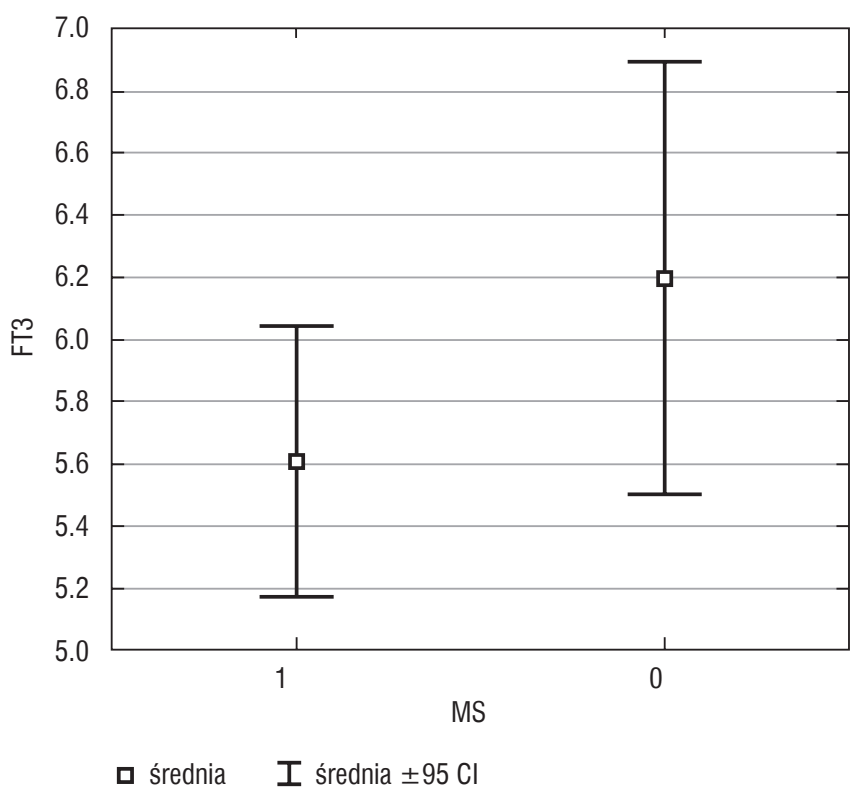

are conflicting. For example, Jin et al. found positive correlation between $\mathrm{BMI}$ and serum concentration of TSH in children and adolescents [13]. On the other hand, Aeberli et al. concluded that TSH was not correlated with body weight, BMI SDS, lean body mass, or body fat percentage in this group of patients [17]. The correlation between TSH level and BMI SDS was not confirmed by our results (Fig. 2). Although we did not show a direct relationship between fat tissue excess and TSH value; the literature data indicate a relationship between its metabolic activity and the thyroid axis function. It was postulated that obese patients have more frequently elevated level of TSH because of resistance in $\mathrm{TSH}$ receptor caused by leptin and insulin resistance [18-19], but these studies were conducted on obese women and pregnant women, so conclusions probably should not be generalised. Even less is known about any clinical consequences of such a phenomenon. It has been postulated that thyroid axis disturbances could be an additional marker of cardiometabolic risk [9]. Moreover, Erdogan et al. found that MS in adults was more common in patients with overt hypothyroidism in comparison with euthyroid participants and ones with subclinical hypothyroidism [20]. There have been no such studies in children and adolescents to date. The results of the present study do not confirm any association between abnormal thyroid axis function (measured as TSH, fT3, and fT4 levels) and the presence of MS in adolescents. No frequent occurrence of overt thyroid diseases was confirmed in that group either. Such an increased incidence reported by research carried out on adults pointed to a potential association between elevated TSH and insulin sensitivity [21]. On the basis of the results of newer publications, the direction of this dependence seems to be the opposite: the insulin resistance in obesity seems to lead to tissue hypothyroidism and subsequent increase in TSH synthesis [2]. 


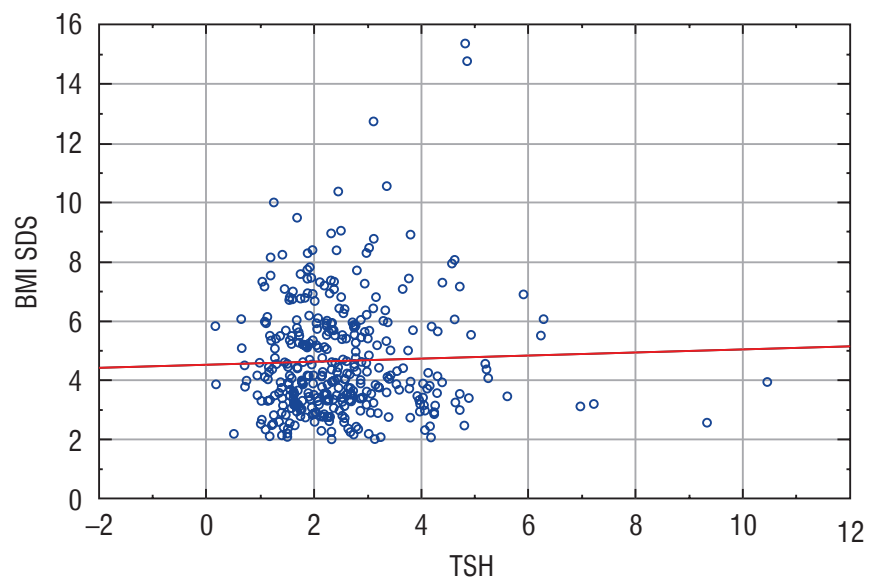

Figure 2. Correlation between BMI SDS and TSH level $[\mu \mathrm{lU} / \mathrm{ml}]$, $r=0.008 ; p>0.05$

The relationship between thyroid function and components of MS has been discussed in a few articles only, with conflicting conclusions [22-24]. Ruhla et al. reported that even a high normal TSH level is associated with greater susceptibility to MS [22]. Other studies, conversely, revealed no association between TSH fT4 and fT3 levels and MS occurrence, similarly to our observation [23-24]. Another aspect analysed in our study was the association of obesity and its metabolic complications with AITD. Some studies point to a potential role of obesity as an environmental factor contributing to the onset and progression of AITD [25]. For example, Hashimoto thyroiditis seems to be more prevalent in patients with polycystic ovary syndrome, in which the development of basic mo-

\section{References}

1. Kelly T, Yang W, Chen CS, et al. Global burden of obesity in 2005 and projections to 2030. Int J Obesity 2005; 32: 1431-1437. doi: 10.1038/ijo.2008.102

2. Fontenelle LC, Feitosa MM, Severo JS, et al. Thyroid function in human obesity: underlying mechanisms. Horm Metab Res 2016; 48: 787-794. doi: 10.1055/s-0042-121421

3. Reinehr T. Thyroid function in the nutritionally obese child and adolescent. Curr Opin Pediatr 2011; 23: 415-420. doi: 10.1097/ MOP.0b013e328344c393

4. Reinehr T. Obesity and thyroid function. Mol Cell Endocrinol 2010; 316: 65-171.

5. Grandone A, Santoro N, Coppola F, et al. Thyroid function derangement and childhood obesity: an Italian experience. BMC Endocr Disord 2010; 10: 8. doi: 10.1186/1472-6823-10-8

6. Witkowska-Sędek E, Kucharska A, Rumińska M, et al. Thyroid dysfunction in obese and overweight children. Endokrynol Pol 2017; 68: 54-60. doi: 10.5603/EP.2017.0007 tions has insulin resistance [26]. Adipokines, such as leptin and adiponectin, seem to play roles in regulating immunity and be links between obesity and autoimmunity [25, 27-34]. Moreover, some authors suggest that a hypoechogenic thyroid ultrasound image, frequently observed in obese patients, may be the early sign of a seronegative AITD and could precede the generation of antithyroid antibodies [3]. On the other hand, many studies deny increased incidence of AITD in obese patients with elevated TSH [34-38]. In the study by Ghergherehchi et al. among patients with obesity and increased TSH levels, only $10.7 \%$ were positive for antithyroid antibodies [39]. In our group $11 \%$ of patients presented with positive antithyroid autoantibodies, which is more than previously reported for an obese Italian population (7\% of obese adolescents in the paper by Grandone et al.) and almost 10 times more often than reported for the normal weight population $(1.2 \%)[5,40]$. The main limitation of our study is its small sample size. All components of MS can be influenced by different factors, e.g. genetic and environmental factors, not only $\mathrm{TSH}$, so it is hard to be sure about its causality. Also, we did not interview our patients about their daily habits (diet, exercise), and these factors could also influence the results. Further clinical, longitudinal studies should be performed to investigate whether thyroid status plays a role in the occurrence of MS or not.

\section{Conclusions}

Isolated, increased TSH levels can be found in a significant percentage of obese adolescents. There is no correlation between TSH, fT3, and fT4 levels and BMI SDS value. Isolated, increased TSH level is not associated with the occurrence of MS in obese adolescents.

7. Marras V, Casini MR, Pilia S, et al. Thyroid function in obese children and adolescents. Horm Res Paediatr 2010; 73: 193-197. doi: $10.1159 / 000284361$

8. Reinehr T, Isa A, de Sousa G, et al. Thyroid hormones and their relation to weight status. Horm Res 2008; 70: 51-57. doi: 10.1159/ 000129678

9. Vanderpump MP, Tumbridge WM. Epidemiology and prevention of clinical and subclinical hypothyroidism. Thyroid 2002; 12: 839-847. doi: 10.1089/105072502761016458

10. Palczewska I, Niedźwiecka Z. Wskaźniki rozwoju somatycznego dzieci i młodzieży warszawskiej. Med Wieku Roz 2001; 5: 1-118.

11. Litwin M, Kułaga Z, Różdżyńska A, et al. Siatki centylowe wysokości, masy ciała i wskaźnika masy ciała dzieci i młodzieży w Polsce wyniki badania OLAF. Standardy Medyczne. Pediatria 2010; 7 : 690-700.

12. Zimmet P, Alberti KG, Kaufman F, et al. IDF Consensus Group. The metabolic syndrome in children and adolescents - an IDF consensus report. Pediatr Diabetes 2007; 8: 299. doi: 10.1111/j.13995448.2007.00271.x 
13. Jin HY. Prevalence of subclinical hypothyroidism in obese children or adolescents and association between thyroid hormone and the components of metabolic syndrome. J Paediatr Child H 2018; 54 : 975-980. doi: 10.1111/jpc.13926

14. Fox CS, Pencina MJ, D'Agostino RB, et al. Relations of thyroid function to body weight: cross-sectional and longitudinal observations in a community-based sample. Arch Intern Med 2008; 168: 587-592. doi: 10.1001/archinte.168.6.587

15. Pesic MM, Radojkovic D, Antic S, et al. Subclinical hypothyroidism: association with cardiovascular risk factors and components of metabolic syndrome. Biotechnol Biotec Eq 2015; 29: 157-163. doi: 10.1080/13102818.2014.991136

16. Nyrnes A, Jorde R, Sundsfjord J. Serum TSH is positively associated with BMI. Int J Obesity 2006; 30: 100-105. doi: 10.1038/sj.ijo.0803112

17. Aeberli I, Jung A, Murer SB, et al. During rapid weight loss in obese children, reductions in TSH predict improvements in insulin sensitivity independent of changes in body weight or fat. J Clin Endocrinol Metab 2010; 95: 5412-5418. doi: 10.1210/jc.2010-1169

18. Topsakal S, Yerlikaya E, Akin F, et al. Relation with HOMA-IR and thyroid hormones in obese Turkish women with metabolic syndrome. Eat Weight Disord 2012; 17: 57-61.

19. Han C, Li C, Mao J, et al. High Body Mass Index Is an Indicator of Maternal Hypothyroidism, Hypothyroxinemia, and Thyroid-Peroxidase Antibody Positivity during Early Pregnancy. Biomed Res Int 2015; 351831. doi: 10.1155/2015/351831

20. Erdogan M, Canataroglu A, Ganidagli S, et al. Metabolic syndrome prevalence in subclinic and overt hypothyroid patients and relation among metabolic syndrome parameters. J Endocrinol Invest 2011; 34: 488-492. doi: 10.3275/7202

21. Chubb SA, Davis WA, Davis TM. Interactions among thyroid function, insulin sensitivity, and serum lipid concentrations: the Fremantle diabetes study. J Clin Endocrinol Metab 2005; 90: 5317-5320. doi: 10.1210/jc.2005-0298

22. Ruhla S, Weickert MO, Arafat AM, et al. A high normal TSH is associated with the metabolic syndrome. Clin Endocrinol 2010; 72 : 696-701. doi: 10.1111/j.1365-2265.2009.03698.x

23. Bermúdez V, Salazar J, Añez R, et al. Metabolic Syndrome and Subclinical Hypothyroidism: A Type 2 Diabetes-Dependent Association. J Thyroid Res 2018; 29: 8251076. doi: 10.1155/2018/8251076

24. Garduño-Garcia JD, Alvirde-Garcia U, López-Carrasco G, et al. TSH and free thyroxine concentrations are associated with differing metabolic markers in euthyroid subjects. Eur J Endocrinol 2010; 163: 273-278. doi: 10.1530/EJE-10-0312

25. Versini $\mathrm{M}$, Jeandel PY, Rosenthal $\mathrm{E}$, et al. Obesity in autoimmune diseases: not a passive bystander. Autoimmun Rev 2014; 13: 981 1000. doi: 10.1016/j.autrev.2014.07.001

26. Arduc A, Aycicek Dogan B, Bilmez S, et al. High prevalence of Hashimoto's thyroiditis in patients with polycystic ovary syndrome: does the imbalance between estradiol and progesterone play a role? Endocr Res 2015; 40: 204-210. doi: 10.3109/07435800.2015.1015730

27. Wilk S, Scheibenbogen C, Bauer S, et al. Adiponectin is a negative regulator of antigen-activated T cells. Eur J Immunol 2011; 41: 2323-2332. doi: 10.1002/eji.201041349

28. Fantuzzi G. Adiponectin in inflammatory and immune-mediated diseases. Cytokine. 2013; 64: 1-10. doi: 10.1016/j.cyto.2013.06.317

29. Gerriets VA, Danzaki K, Kishton RJ, et al. Leptin directly promotes T-cell glycolytic metabolism to drive effector T-cell differentiation in a mouse model of autoimmunity. Eur J Immunol 2016; 46: 19701983. doi: 10.1002/eji.201545861

30. Obeid S, Wankell M, Charrez B, et al. Adiponectin confers protection from acute colitis and restricts a $B$ cell immune response. J Biol Chem 2017; 292: 6569-6582. doi: 10.1074/jbc.M115.712646

31. Love TJ, Zhu Y, Zhang $Y$, et al. Obesity and the risk of psoriatic arthritis: a population-based study. Ann Rheum Dis 2012; 71: 12731277. doi: 10.1136/annrheumdis-2012-201299

32. Gremese E, Tolusso B, Gigante MR, Ferraccioli G. Obesity as a risk and severity factor in rheumatic diseases (autoimmune chronic inflammatory diseases). Front Immunol 2014; 5: 576. doi: 10.3389/ fimmu.2014.00576

33. Khalili $H$, Ananthakrishnan AN, Konijeti GG, et al. Measures of obesity and risk of Crohn's disease and ulcerative colitis. Inflamm Bowel Dis 2015; 21: 361-368. doi: 10.1097/MIB.0000000000000283

34. Ljung L, Rantapaa-Dahlqvist S. Abdominal obesity, gender and the risk of rheumatoid arthritis - a nested case-control study. Arthritis Res Ther 2016; 18: 277. 10.1186/s13075-016-1171-2

35. Rotondi M, Leporati P, La Manna A, et al. Raised serum TSH levels in patients with morbid obesity: is it enough to diagnose subclinical hypothyroidism? Eur J Endocrinol 2009; 160: 403-408. doi: 10.1530/EJE-08-0734

36. Reinehr T, Hinney A, de Sousa G. et al. Definable somatic disorders in overweight children and adolescents. J Pediatr 2007; 150: 618622. doi: 10.1016/j.jpeds.2007.01.042

37. Stichel H, l'Allemand D, Grüters A. Thyroid function and obesity in children and adolescents. Horm Res 2000; 54: 14-19. doi: 10.1159/000063431

38. Bhowmick SK, Dasari G, Levens KL, et al. The prevalence of elevated serum thyroid-stimulating hormone in childhood/adolescent obesity and of autoimmune thyroid diseases in a subgroup. J Natl Med Assoc 2007; 99: 773-776.

39. Ghergherehchi R, Hazhir N. Thyroid hormonal status among children with obesity. Ther Adv Endocrinol Metab 2015; 6: 51-55. doi: 10.1177/2042018815571892

40. Rallison ML, Dobyns BM, Keating FR, et al. Occurrence and natural history of chronic lymphocytic thyroiditis in childhood. J Pediatr 1975; 86: 675-682. 